\title{
Reading and Translation: Suggestions for Integration
}

\author{
Musallam Al-Ma'ani ${ }^{1}$, Amel Salman ${ }^{1} \&$ Nafla S. Kharusi ${ }^{1}$ \\ ${ }^{1}$ Department of English, Sultan Qaboos University, Muscat, Oman \\ Correspondence: Musallam Al-Ma'ani, P. O. Box 42, Department of English, Sultan Qaboos University, Muscat, \\ Oman. E-mail: Musallam@squ.edu.om
}

Received: May 9, 2014 Accepted: September 1, 2014 Online Published: October 1, 2014

doi:10.5539/ijel.v4n5p35 URL: http://dx.doi.org/10.5539/ijel.v4n5p35

\begin{abstract}
Students entering undergraduate translation programs tend to rely on their instructors' general knowledge, and indeed on information of whatever kind that can be gleaned from this source. At this stage, they still lack real world knowledge and often language competence too. Hence, instructors worry about what they should include in their introductory courses for such students. The present study tries to determine whether a learner-centered approach to the problem, in which reading parallel texts and exposing beginners to information on a topic, its vocabulary and structure, helps with understanding a source text and producing its target equivalent.
\end{abstract}

Keywords: Arabic, parallel texts, reading, teaching, translation

\section{Introduction}

Historically, translation has played a key role in inter-human communication, and especially in providing access to seminal texts across different domains. Thus a prominent feature of translation activity is the exchange of knowledge and scholarly work, particularly in scientific, legal, and cultural disciplines, enriching not only the knowledge base itself but also languages and culture. Each text set for translation has its own typology, formal structures, coherence, cohesive devices, lexico-syntactic, and real world properties. Hence, translators are obliged to adopt diverse strategies to carry over a message from one language to another. Technical translation, for example, because it encompasses a wide range of specialized texts, requires a high degree of subject knowledge and mastery of relevant terminology. Translators must be sensitive to this, because "a mistake in the translation of a technical document cannot be compared, for example, to a mistake in translating a novel" (Al-Ma'ani, 2012, p. 207).

Translation, thus, requires not only awareness of specific terminology, but also knowledge of a text's strategies, style and register, and ideas about how these are to be rendered in the target text. Translators mediate between the source and target cultures and readers and so must consider many of these factors. In a word, translation is so broad and variegated that instructors face a daunting task when trying to delineate its scope and design courses for undergraduates.

Instruction is usually shaped to help students develop a range of skills around language, text, subject, culture and transfer competence (Neubert, 2000), and it is common to find different competencies gathered and tested in a single course. This kind of teaching, though difficult for instructors, not only highlights the language competence students already have (or should have), but also reveals their level of readiness to absorb knowledge and deal with texts from diverse specializations.

Because students at this stage are mere beginners, instructors must decide what they should be looking at, for example translation difficulties or translation problems. Nord (2005) argues that translation difficulties arise from deficient linguistic, cultural or translational competence, while translation problems will always remain - faced even by professionals. It must be emphasized, however, that at this stage students' major weakness lies in linguistic, cultural and translational competence.

Indeed, students face two challenges: learning translation and learning through translation. The former involves acquiring translation competence and the latter learning language or acquiring knowledge through translation. Postgraduates and undergraduates are different. Undergraduates are new to the issues listed above, while postgraduates will usually have language and other abilities they have developed as undergraduates. Thus, beginner translation programs are often designed to tackle problems related to transfer competence and may also include such helpful language courses as reading and writing. Thus Sultan Qaboos University's program offers 
courses not only focusing on translation skills but also on reading, writing and speaking, as a way of improving students' overall English proficiency. Students also take courses to improve their Arabic.

Because beginning undergraduates are still in the process of language acquisition, "we cannot expect them to have full source language and target-language proficiency from the start" (Nord, 2005, p. 74). Yet translators "must have sufficient mastery of the source language, or foreign language, sufficient to enable [them] to translate it without error. There must be no mistranslation, whether caused by carelessness or a misunderstanding of the original" (Kingscott, 2002, p. 247). And the most basic language competence should include at least "the ability to put words together to form phrases and sentences that express our thoughts" (Fromkin \& Rodman, 1993, p. 73). By contrast, of course, for professional translators or postgraduate students language is not an issue.

It is not only how SL is organized or what the words mean that matters. Students should also be able to understand how structure and meaning are relevant to the situation in which a translation is carried out. As Fawcett notes, there are two consequences for translation when languages vary: "[f]irstly the meaning that is transferred will be decided by situation and context, not by the dictionary and, secondly, the transfer will nearly always involve some form of loss or change" (1997, pp. 25-26).

Furthermore, since knowledge is not static, it cannot be transmitted to learners in a classroom setting or through instructors. Undergraduates in translation programs will routinely face a wide range of texts, each in itself unique because of factors and conditions under which it was written. Because students find it hard to handle such diversity, they should be encouraged to read around the topics they are asked to address. Instead of being mere receivers of knowledge, they should know how and where to find it and be able to take decisions about meaning comprehension and meaning-making, both of which involve three levels: syntactic, semantic and pragmatic. Also, students should be encouraged to read parallel copra because they are "a richer resource . . . than conventional resources such as dictionaries" (Pearson, 2003, p. 15).

Assessment of student translation in the early stages should focus on translation competence knowledge. This means target language knowledge, text-type knowledge, source language knowledge, real world knowledge, and contrastive knowledge (Bell, 1991). This implies a binary process, targeting comprehension and understanding of the source text and production of the target text. Students often lack sufficient general knowledge to effectively translate technical or culturally-loaded concepts and deficient knowledge of a given subject and its associated lexical items and syntactic structures is often seen in translation errors. As Kiraly notes, "a flaw in most translation programs is the lack of emphasis on reading and using parallel texts in the L2" (1995, pg. 110). Encouraging students to read parallel texts, he feels, enables them to develop a constructive process in which an internal representation of knowledge and a personal interpretation of experience are built. This representation is not static but open to change, forming a foundation on which other knowledge structures can be erected (Bednar, Cunningham, Duffy, \& Perry, 1992).

It is also important to note that translation theories, especially since the 1990 s, have emphasized a learner-centered pedagogy, focusing, as Tennent (2005) argues, on developing students' autonomy and self-confidence, moving away from top-down, teacher-centered approaches to pedagogy. In his work on a learner-centered approach to Arabic technical translation, Al-Ma'ani (2012) emphasizes the importance of three stages in approaching the task. These are (1) source text (ST) understanding; (2) comparative analysis (CA); and (3) target text (TT) production. What is involved is selection of the material used both in parallel texts and in tests; the development of assessment criteria for evaluating students' ST understanding and TT production through assignments; and a comparative analysis stage which works as a bridge between the two other stages, while giving allowing students to determine 'untranslatable' components which pose difficulties at the TT production stage. In conducting the present study students went through these stages.

The aim of the present study, then, is to determine whether the application of a learner-centered approach, with particular reference to students reading parallel texts, has an effect on subsequent performance in translating a text on the same subject. In other words, it asks if information on a topic and exposure to its associated vocabulary and structure, coupled with an approach such as that proposed by González Davies and Scott-Tennent (2005), enhances students' translation skills.

\section{Method}

The study was conducted in the Fall Semester of 2011 and involved a group comprising 14 second-year students registered in a course called Introduction to Translation. The students, at this stage had no preconceived notions of translation, nor had they done any prior translating or been exposed to extensive reading programs. The course, first in a compulsory series taken by Translation majors, introduced students to the English-Arabic translation of various text types and genres. Through practice, they were introduced to the basic principles of translation and 
due consideration was given to critical aspects of the process, such as source text analysis and production of a target text with a focus on meaning at all levels. As is the case with all courses taken by these students, developing language competence was a main objective.

Prior to taking the course, students were required to attend six English language skills classes over a period of two semesters. Completing them successfully ensured a basic competence in English before they began studying their specializations. Meanwhile, they were also enrolled in introductory linguistics classes.

To ensure they went through the three stages noted by Al-Ma'ani (2012) students were required to read various articles assigned by the instructor prior to facing any translation work. They were emailed a folder once a week consisting of three or four authentic articles written in the source language (SL), in this case English. The articles dealt with the same topic or subject matter, such as e-commerce, women, violence, or modern slavery. Various parts of the articles were highlighted, representing challenges at different levels, such as lexical items and terminology, idiomatic expressions, and complex structures. Students were then given a week to complete their assignment, which included reading all the articles, familiarizing themselves with the topic, and translating the sections highlighted. They were also encouraged to search for more articles, including those written in Arabic (TL), in order to ensure that they were also exposed to the TL vocabulary of the same subject domain.

The second step involved specifying for students the approach to be adopted in the translation process. They were encouraged to follow the original English text as closely as possible, while remembering the structural and organizational differences between the source and target languages. They were not, however, encouraged to express their opinions or change facts expressed in the source text or omit parts perhaps essential to meaning.

The whole procedure, from the reading of parallel texts in both languages to the translating, was important because two essential stages were covered: ST understanding and TT production. Even if TT is linguistically acceptable, TT information and meaning should still be compatible with what has been mentioned in the ST. In other words, the translation should not involve alteration of the original meaning, intent, information flow, or emphasis of the source text. ST understanding is important and critical in revealing student mistakes as a result of ST comprehension. It involves the ability to understand the meaning of ST words, sentences or larger sections, within both their specialized or general contexts. A particular lexical item may, of course, function in different ways, depending on context.

In TT production, students had to follow the same pattern, including ST textual organization and composition. Because the situation in which their translations would be received resembled the source text's, this procedure replicated the conditions under which the source text was produced. This includes spelling, subject-verb agreement, tense, word form, word order, modifiers, fragments and punctuation, as well as unfinished translation and omissions of sentences or sections. It entailed insertion of 'extra' details or omission of important information in a way that rendered the TT meaning inconsistent with the ST's original sense. This also refers to providing more than one option at the lexical and sentence levels. Such steps were taken to preclude erroneous student assumptions about readers' previous knowledge of the objects and phenomena referred to in the translation.

In class, both source texts and translations were discussed in detail. First the main idea was addressed and then students were asked to provide translations of selected parts, including sections not highlighted by the instructor or translated by the students themselves. The translations were written on the whiteboard for the rest of the class to see (Table 1). Discussion and activity were loosely based on González Davies and Scott-Tennent's five-phase sequence in the problem-solving process of translation (2005, p. 163):

1. general approach

2. problem-spotting

3. brain-storming and choosing strategies

4. brain-storming and choosing procedures

5. choosing a final solution

All students were involved in error spotting and correcting, as well as in discussing different aspects of the translation, such as comparison of lexical items and their target language equivalents and alternative sentence structures. Process-oriented questions such as those suggested by Gile (1994) were asked: "Why this choice?", "Did you consider alternatives?", "If so, what made you choose this solution?", and "Are you satisfied with this solution as far as logic/clarity/language is concerned?" (cited in Olk, 2003, p. 173). According to Gile, such an 
approach results in a "considerable reduction in the number of errors due to faulty analysis of the source text" (1994, p. III).

Table 1. Example of student translations from English to Arabic

\begin{tabular}{|c|c|}
\hline Source Text & Translation provided by some students \\
\hline \multirow[t]{4}{*}{$\begin{array}{l}\text { "The high-level meeting in Oslo } \\
\text { paves the way for some important } \\
\text { initiatives." }\end{array}$} & 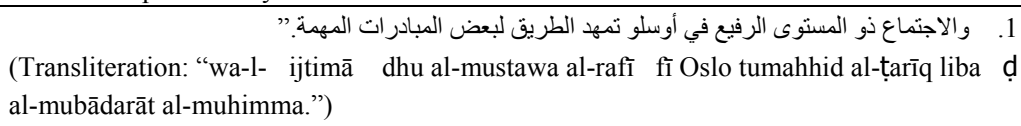 \\
\hline & 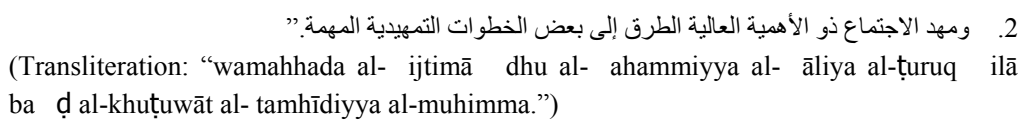 \\
\hline & 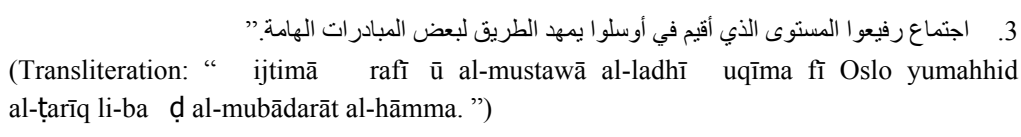 \\
\hline & 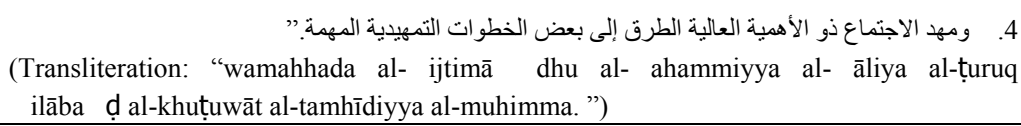 \\
\hline
\end{tabular}

Note. The transliteration provided follows the IJMES Transliteration System.

Table 1 illustrates some translations that were provided by students and examined and discussed in class for language errors, suitability, specificity, and acceptability of the lexical equivalents provided for "high-level meeting" and "some important initiatives". There were errors, for instance, related to verb tense, subject-verb gender agreement, spelling and word choice. Classroom discussions might also include the different translation strategies and techniques within the framework of the texts reviewed.

Assessment of this course involved three tests and a final exam, all of which required students to translate authentic text passages from English to Arabic. In two of the tests, students were given texts to translate on topics related to those they had studied throughout the semester. The final exam comprised two passages, one of which was on a topic with which they were familiar, while the other dealt with a new subject. All passages included in the tests and final exam were new and never discussed before and students were not allowed to use dictionaries or reference material. It is worth mentioning that since the course was the students' first in translation, and since at this stage they had not received any linguistics teaching, assessment of items such as the overall structure of the text, register, style, and usage was not rigid. Focus was placed, instead, on lexical choice and overall subject matter, as well as grammatical details.

\section{Results and Discussion}

Analysis of student translation in the tests and final exam highlights some significant points. When translating texts dealing with familiar topics, they demonstrated a good grasp of vocabulary, including names of organizations. This was evident in their lexical choices, such as the use of more precise and specific vocabulary. Also, they expressed source text points in the target language clearly and effectively. As a result, they avoided some of the most commonly encountered translation mistakes, such as incomplete passages, misunderstanding of the source text, mistranslation into the TL, wrong word choice and register, and parts translated too freely. In translating unfamiliar texts, however, not only did the students make the familiar mistakes associated with a lack of understanding of the topic in question; they also produced translations that were often too literal, with a significant number of inconsistencies and ambiguous contextually inadequate renderings. For example, students unfamiliar with "the Center for Remote Sensing" rendered it as (Note 1):

$$
\begin{aligned}
& \text { "مركز الإحساس التلقائي" ( markaz al- iḥsāsal-tilqā ī) } \\
& \text { "automatic feeling center" } \\
& \text { "مركز الأبحاث عن بعد” ( markaz al- abḥāth an bu d) } \\
& \text { "remote research center" } \\
& \text { " (markaz al-taḥakkum an bu d) } \\
& \text { "remote control center" }
\end{aligned}
$$




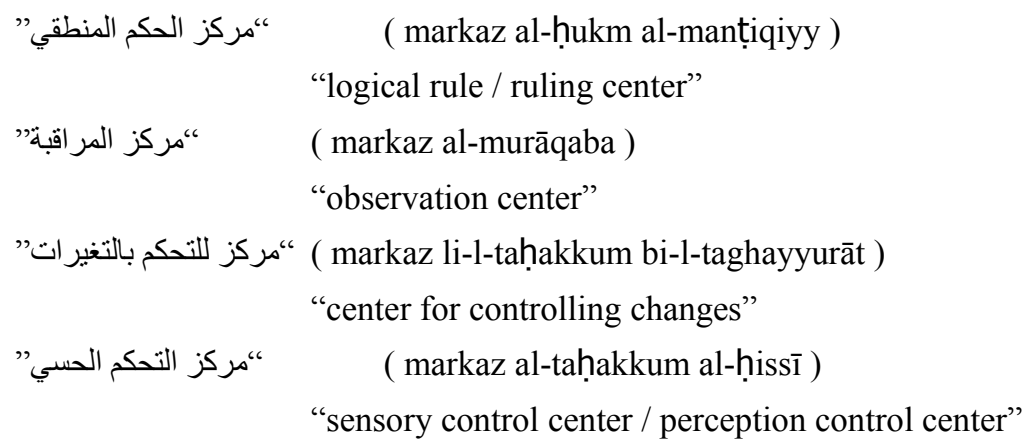

Another example illustrates a misunderstanding of the source text which resulted in mistranslation, “...said cyclical variation in rainfall as shown by previous drought periods must be considered, explaining that dry spells in the Sahel fluctuated drastically almost every seven years". This was rendered by two students as:

$$
\begin{aligned}
& \text { “"..قال ان التتوع الدوري في سقوط الامطار كما شو هد خلال فتر ات الجفاف السابقة يجب وضعها بعين الاعتبار، موضحا أن الجفاف الذي حل بساحل } \\
& \text { يمر بشكل دوري على الأكثر كل سبع سنوات." }
\end{aligned}
$$

(Transliteration: “..qāâla inna al-tanawwu al-dawrī fī suqūṭ al-amțār kamā shūhida khilāl fatarāt al-jafāf al-sābiqa yajib wạ̣ ahā bi ayn al-i tibār, muwaḍ̣̣ị̣an anna al-jafāf al-ladhi ḥalla bisāḥil yamurr bishakl dawrī alā al- akthar kul sab sanawāt."

Literal translation of the student's rendering: “...said that cyclical variation in rainfall as was seen during the previous dry periods has to be taken into consideration, explaining that the drought that befell a coast/Sahel passes in a periodic way mostly every seven years."

and:

“،.أخبر... أن دورة التبخر في هطول الأمطار كما هو واضح في الفترات السابقة للجفاف يجب أخذها بعين الاعتبار. وشرح ان الجفاف ينتشر في

(Transliteration: “.. akhbara... anna dawrat al-tabakhkhur fĩ huțūl al- amțār kamā huwa wāḍiḥ fî-l-fatarāt al-sābiqa li-l-jafăf yajib akhdhahā bi ayn al- i tibār. Washaraḥa anna al-jafăf yantashir fi al-sāḥil bi-shakl mudammir taqrīban kul sab sanawāt."

Literal translation of the student's translation: “...told...that the cycle of evaporation in rainfall as it is evident in previous times of drought have to be taken into consideration. And explained that drought spreads in the coast/Sahel in a destructive way about every seven years."

Table 2 represents students' average scores on two criteria: misunderstanding of the source text (and thus mistranslation into the target language) and wrong lexical choice. The scores are out of ten.

Table 2. Students' average scores

\begin{tabular}{llcccl}
\hline Assessment Criteria & Test 1 & Test 2 & Test 3 & $\begin{array}{l}\text { Final exam } \\
\text { Part 1 }\end{array}$ & $\begin{array}{l}\text { Final exam } \\
\text { Part 2 }\end{array}$ \\
\hline $\begin{array}{l}\text { Misunderstanding of the source text \& mistranslation } \\
\text { into the TL }\end{array}$ & 8.45 & 8.24 & 6.43 & 8.18 & 7.64 \\
\hline Wrong word choice for subject-specific words & 8.93 & 8.71 & 6.60 & 8.46 & 7.90 \\
\hline
\end{tabular}

As the table shows, students performed satisfactorily when they were familiar with the source text's subject matter.

Unlike teacher-centered instruction, this learner-centered approach reinforced the various aspects of a successful translation process, such as the importance of familiarity with the subject matter. In addition to learning how to translate, edit, and develop an ability to critique translations, students were also able to learn how others might interpret the same text differently and how such an interpretation was then rendered in the target language.

Lee-Jahnke insists that encouraging students to assume responsibility for their learning, as happens in task or project-based teaching or, as in the present case, reading for familiarity with a topic, "increase[s] their ability to infer their learned knowledge and to apply it again in similar situations" $(2005$, p. 362). She adds that translation teaching must be oriented towards stimulating the mechanisms involved in the learning process, these being "inference, judgment, diagnostic ability, and reasoning by analogy" (Lee-Jahnke, 2005, p. 363). Similarly, 
González Davies and Scott-Tennent refer to a knowledge that "is not put across only by the teacher, but is also constructed and reconstructed by the students according to their previous knowledge (transformation vs. transmission)" (2005, p. 169). Within such an approach, they go on to say, students "build their knowledge not only through self-study, but also through social interaction" (2005, p. 169). Translation competence in areas of cultural reference also develops when students are directed towards "problem-spotting", "solving strategies", and "procedures" related to such references (González Davies \& Scott-Tennent, 2005, p. 163). Hence, a syllabus for a first translation course should be based on a pedagogy embracing all these components of the translation learning process. Instructional implications should also include the introduction of factual reference sources and material on the topics students will tackle. Engaging students in reading parallel texts and exposing them to lexical variety, a broad range of syntactical structures specific to different genres, and familiarizing them with cultural references, not only enhances their translation training and language development but also enriches their world knowledge.

\section{References}

Al-Ma'ani, M. (2012). A learner-centered approach to technical translation in undergraduate programmes.Contributions from Arabic. The Linguistics Journal, 6(1), 205-217.

Bednar, A., Cunningham, D., Duffy, T., \& Perry, J. (1992). Theory into practice: How do we link? In T. M. Duffy \& D. H. Jonassen (Eds.), Constructivism and the technology of instruction: A conversation (pp. 17-34). London: Lawrence Erlbaum Associates.

Bell, R. (1991). Translation and translating. London: Longman.

Fawcett, P. (1997). Translation and language: Linguistic theories explained. Manchester: St Jerome Publishing.

Fromkin, V., \& Rodman, R. (1993). An introduction to language. Orlando: Harcourt Brace Jovanovich.

Gile, D. (1994). The process-oriented approach in translation training. In C. Dollerup \& A. Lindegaard (Eds.), Teaching translation and interpreting (2): Insights, aims, visions (pp. 107-112). Amsterdam \& Philadelphia: John Benjamins. http://dx.doi.org/10.1075/btl.5.17gil

González Davies, M. \& Scott-Tennent, C. (2005). A problem-solving and student-centred approach to the translation of cultural references. Meta: Translators' Journal, 50(1), 160-179. http://dx.doi.org/10.7202/010666ar

Kingscott, G. (2002). Technical translation and related disciplines. Perspectives, 10(4), 247-255. http://dx.doi.org/10.1080/0907676X.2002.9961449

Kiraly, D. (1995). Pathways to translation: Pedagogy and process. Kent, Ohio: Kent State University Press.

Lee-Jahnke, H. (2005). New cognitive approaches in process-oriented translation training. Meta: Translators' Journal, 50(2), 359-377. http://dx.doi.org/10.7202/010942ar

Neubert, A. (2000). Competence in language, in languages, and in translation. In C. Schäffner \& B. Adab (Eds.), Developing translation competence (pp. 3-18). Philadelphia, PA, USA: John Benjamins Publishing Company. http://dx.doi.org/10.1075/btl.38.03neu

Nord, C. (2005). Text analysis in translation: Theory, methodology, and didactic application of a model for translation-oriented text analysis. New York: Rodopi.

Olk, H. (2003). Cultural knowledge in translation. ELT Journal, 57(2), 167-174. http://dx.doi.org/10.1093/elt/57.2.167

Pearson, J. (2003). Using Parallel Texts in the Translator Training Environment. In Z. Federico, S. Bernardini, \& D. Stewart (Eds.), Corpora in Translator Education (pp. 15-24). Manchester: St Jerome Publishing.

Tennent, M. (Ed.). (2005). Training for the new millennium: Pedagogies for translation and interpreting. Philadelphia, PA, USA: John Benjamins Publishing Company. http://dx.doi.org/10.1075/btl.60

\section{Note}

Note 1. Since word order differs in the two languages, it is modified in the literal translations provided against each Arabic translation. 


\section{Appendix}

\section{Transliteration Guide}

Adapted from IJMES Transliteration System for Arabic, Persian and Turkish.

\begin{tabular}{|c|c|c|c|c|}
\hline \multicolumn{5}{|l|}{ Consonants } \\
\hline 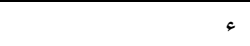 & & & s & $\mathrm{m}$ \\
\hline ب & $\mathrm{b}$ & & ن & $\mathrm{n}$ \\
\hline ت & $\mathrm{t}$ & & 。 & $\mathrm{h}$ \\
\hline$\doteq$ & th & & g & $\mathrm{w}$ \\
\hline ج & $\mathrm{j}$ & & ي & y \\
\hline$\tau$ & ḥ & & 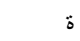 & a (in construct state: at) \\
\hline$\dot{\tau}$ & $\mathrm{kh}$ & & 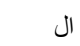 & al- or $-1-$ \\
\hline د & $\mathrm{d}$ & & & \\
\hline$\dot{j}$ & $\mathrm{dh}$ & Vowels & & \\
\hline J & $\mathrm{r}$ & & I & $\overline{\mathrm{a}}$ \\
\hline j & $\mathrm{z}$ & & g & $\overline{\mathrm{u}}$ \\
\hline س س & $\mathrm{s}$ & & ي & $\overline{1}$ \\
\hline ش & $\mathrm{sh}$ & & & a \\
\hline ص ص ص & ș & & ' & $\mathrm{u}$ \\
\hline 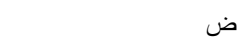 & d & & & $\mathrm{i}$ \\
\hline$b$ & $t$ & & 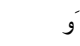 & au or aw \\
\hline ط & $z$ & & بَي & aior ay \\
\hline$\varepsilon$ & & & يّ & iyy (final form: $\overline{1}$ ) \\
\hline$\dot{\varepsilon}$ & $\mathrm{gh}$ & & $\ddot{g}$ & uww (final form: $\bar{u}$ ) \\
\hline ف & $\mathrm{f}$ & & & \\
\hline ق & $\mathrm{q}$ & & & \\
\hline 5 & $\mathrm{k}$ & & & \\
\hline J & 1 & & & \\
\hline
\end{tabular}

\section{Copyrights}

Copyright for this article is retained by the author(s), with first publication rights granted to the journal.

This is an open-access article distributed under the terms and conditions of the Creative Commons Attribution license (http://creativecommons.org/licenses/by/3.0/). 